\title{
HUMAN AMNIOTIC MEMBRANE GRAFTING: A BOON IN OCULAR CHEMICAL INJURIES
}

Shashikala. P, Mangalagowri,

1. Assistant Professor/Specialist. Department of Ophthalmology, ESIC Medical College and PG Institute of Medical Sciences \& Research Center, Bangalore. India.

2. Assistant Professor/Specialist. Department of Ophthalmology, ESIC Medical College and PG Institute of Medical Sciences \& Research Center, Bangalore. India.

\section{CORRESPONDING AUTHOR:}

Dr. Mangalagowri, ESIC MC \& PGIMSR, Rajajinagar, $3^{\text {rd }}$ block, Bangalore, Karnataka- 560010.

E-mail: drshashikala9@gmail.com, esicmh@gmail.com

Ph: 00919448087334

INTRODUCTION: Amniotic membrane is the innermost layer of the fetal membranes. It has a stromal matrix, a collagen layer, and an overlying basement membrane with a single layer of epithelium. (1) Amniotic membrane has unique properties including anti-adhesive effects, bacterio-static properties, wound protection, pain reduction, and epithelialisation effects. Another characteristic of amniotic membrane is the lack of imunogenicity. (2) Amniotic membranes have been used as a dressing to promote healing of chronic ulcers of the leg and as a biological dressing for burned skin and skin wounds. ${ }^{(3,4)}$ It has also been used in surgical reconstruction of artificial vagina, for repairing omphaloceles, and to prevent tissue adhesion in surgeries of the abdomen, head, or pelvis. ${ }^{(5,6)}$ Amniotic membrane has been successfully used in ocular conditions like persistent epithelial defects (7), pterygium, (8) Symblepharon (9) and for ocular surface reconstruction. $(10,11)$ The purpose of this study was to evaluate the use of cryopreserved Human amniotic membrane graft( HAMT), with or without limbal autograft transplantation (LAT) in patients with previous and fresh chemical eye injuries respectively. Institutional ethical committee approval was obtained.

MATERIALS AND METHODS: Six cases of fresh (group 1) and four cases of previous ocular chemical injuries (group 2) from Jan 2011 to Dec. 2011 were managed by using human amniotic membrane grafting as the treatment modality. Both groups received a detailed ophthalmic examination including lid and ocular motility, extraocular examination, visual acuity, tonometry, and slit-lamp and fundus examination. Ultrasonography was performed in patients when the fundus was not visible. Patients in group-1 were initially treated with copious saline irrigation, topical antibiotics, steroids, cycloplegics, anti glaucoma agents and preservative- free tear substitutes and were evaluated according to the Roper-Hall classification. (12) Diagnosis and grading of limbal stem cell deficiency for patients in group 2 were done on a clinical basis, according to the presence of conjunctival epithelial invasion, vascularization, and chronic inflammation of the corneal surface. Eyes with total conjunctivalization of the corneal surface were evaluated as severe or total limbal stem cell deficiency. Symblepharon was graded according to the quadrants involved as mild (less than one quadrant), moderate (one to two quadrants), or severe (more than two quadrants).All individuals gave informed consent before surgery. All cases had processed cryo preserved HAMT. 
Amniotic membrane graft procurement, processing and preservation: Human amniotic membrane is obtained from prospective donors undergoing Caesarean section, who are negative for communicable diseases including HIV, hepatitis B and C and syphilis. Different protocols exist for the processing and storage. $(13,9)$ According to Kim et al, (13) the placenta is cleaned with balanced salt solution containing a cocktail of antibiotics $(50 \mathrm{mg} / \mathrm{ml}$ penicillin, $50 \mu \mathrm{g} / \mathrm{ml}$ streptomycin, $100 \mathrm{mg} / \mathrm{ml}$ of neomycin as well as $2.5 \mathrm{mg} / \mathrm{ml}$ of amphotericin B) under sterile conditions. The amnion is separated from the chorion by blunt dissection. The separated membranes are cut in different sizes placed on nitrocellulose paper strips with the epithelial side up. Dulbecco Modified Eagles Medium/glycerol (1:1) is used for cryopreservation and the tissues are frozen at -80 degrees until further use. (14) Amnion stored in 50-85\% glycerol is reliable and effective for over a year, with the added advantage of antibacterial properties.(15) Human AM deprived of amniotic epithelial cells by incubation with EDTA when freeze dried, vacuum packed and sterilized with gamma-irradiation at $25 \mathrm{kGy}$ retained most of the physical, biological and morphologic characteristics of cryopreserved AM. (16

SURGICAL PROCEDURE: After the peribulbar anesthesia, the epithelial defect was debrided. Pannus, if present, was resected by separating it carefully from the cornea with the help of 15 no. Blade or Vanna scissors. The amniotic membrane was placed covering the entire cornea with epithelial surface up. (17) And sutured to the cornea with 10-0 nylon interrupted perilimbal sutures, anchored to episclera by 8-0 Vicryl sutures. In cases where symblepharon release was required, it was excised and the amniotic membrane was placed to cover the entire exposed area of the sclera and sutured. A symblepharon ring was placed which was removed after a week. In one patient, where limbal stem cell transplant was required, the lenticule of conjunctivolimbal tissue was harvested from the contra lateral normal eye and was sutured at limbus after HAMT with 10-0 nylon sutures. All patients received a combination of Moxifloxacin and Prednisolone acetate eye drops 6 times a day for 1 week and then tapered over 5 weeks, lubricants 4 times daily for 6 weeks. The cases were followed on $1^{\text {st }}$ day, $1^{\text {st }}$ week, $1^{\text {st }}$ month, $6^{\text {th }}$ month and $1^{\text {st }}$ year. Outcome measures were, 1 . Success for epithelial healing; defined as complete restoration of corneal epithelium with no residual defect. 2. Ocular surface reconstruction; restoration of corneal and conjunctival epithelium, reduction in inflammation, reduction in the extent of symblepharon (by more than 3 clock hours), restoration of ocular motility and lack of recurrence and scarring as compared with preoperative status. HAMT was considered being failure if no symptomatic relief or worsening pain, watering and photophobia, conjunctivalization and vascularization at final follow up in comparison to preoperative status.

RESULTS: Out of ten patients, seven were men (70\%) and the age of patients ranged from 8 to 56 years with a mean of 30.9 years. All cases were affected by alkali.

Amniotic membrane transplantation was performed as soon after admission as possible (1-2days) for acute burn patients while, previous burn cases were taken for elective HAMT. The average time from the injury to presentation was 31.2 hours (range, 6-144hours) in group-1 while, it was four months to nine years in group-1. Complete corneal epithelialization with disintegration of HAMT after surgery was 33 days (range, 24-44 days) in group-1 and 46 days (range, 26-94 days) in group-2. Symblepharon neither formed in any acute nor recurred in previous chemical injury cases following HAMT and all had full ocular movements $1100 \%$ success rate). Following HAMT, there was a dramatic reduction in the symptoms such as foreign body sensation, pain, and photophobia and the time taken to reduce the symptoms was 3.5 days 
(range, 1-10 days) in group-1 and 17.5 days (range, 5-33 days)in group-2. Eighty three percent ( 5 of 6 ) in group-1 and 75\% (3 of 4) in group-2 had improved post-operative visual status while, one each in both had persistent epithelial defect, secondary glaucoma and no improvement in final visual outcome. Two cases with pre and post HAMT pictures shown in figures 1-3 and 4-6.

Table-1. Demographic and clinical characteristics of our patients

\begin{tabular}{|c|c|c|c|c|c|c|c|c|}
\hline $\begin{array}{l}\text { No./Age/ } \\
\text { gender }\end{array}$ & Eye & Findings & $\begin{array}{l}\text { Primary } \\
\text { Dx }\end{array}$ & $\begin{array}{l}\text { Duration } \\
\text { since } \\
\text { burn }\end{array}$ & Procedure & $\begin{array}{l}\text { Disintegration } \\
\text { of HAMT and } \\
\text { Ed heal } \\
\text { time(days) } \\
\text { /sympt } \\
\text { reductn } \\
\text { time(days) }\end{array}$ & $\begin{array}{l}\text { Preop } \\
\text { BCVA }\end{array}$ & $\begin{array}{l}\text { Postop } \\
\text { BCVA }\end{array}$ \\
\hline \multicolumn{9}{|c|}{$\begin{array}{l}\text { Acutechemic } \\
\text { al burn }\end{array}$} \\
\hline $1 / 42 / \mathrm{M}$ & $\mathrm{RE}$ & CED,SC,PLI & Gr 3 alk & 6 hours & HAMT & $44 / 3$ & $\mathrm{CF}$ & $6 / 12$ \\
\hline $2 / 44 / \mathrm{M}$ & LE & CED,SC,PLI & Gr 3 alk & 6 days & HAMT & $36 / 10$ & $\mathrm{CF}$ & $\mathrm{CF}$ \\
\hline $3 / 56 / \mathrm{M}$ & $\mathrm{LE}$ & CED,SC,PLI & Gr 2 alk & 12 hours & HAMT & $24 / 1$ & $6 / 60$ & $6 / 12$ \\
\hline $4 / 8 / F$ & $\mathrm{RE}$ & CED,SC,PLI & Gr 2 alk & 9 hours & HAMT & $24 / 1$ & CF & $6 / 60$ \\
\hline $5 / 42 / \mathrm{M}$ & $\mathrm{RE}$ & CED,SC,PLI & Gr 3 alk & 10 hours & HAMT & $44 / 3$ & $\mathrm{CF}$ & $6 / 18$ \\
\hline $6 / 17 / \mathrm{M}$ & LE & CED,SC,PLI & Gr 3 alk & 24 hours & HAMT & $26 / 3$ & CF & $6 / 18$ \\
\hline \multicolumn{9}{|l|}{$\begin{array}{l}\text { Chronic } \\
\text { chemical } \\
\text { burn }\end{array}$} \\
\hline $1 / 8 / F$ & $\mathrm{RE}$ & MS,PLSCD & Gr 2 alk & $2 y r s$ & $\begin{array}{l}\text { SR+HAMT } \\
+ \text { LAT }\end{array}$ & $34 / 5$ & $6 / 60$ & $6 / 36$ \\
\hline $2 / 44 / \mathrm{M}$ & $\mathrm{LE}$ & SS,TLSCD & Gr 4 alk & 4 month & SR+HAMT & $94 / 33$ & $\mathrm{CF}$ & $\mathrm{CF}$ \\
\hline $3 / 24 / \mathrm{M}$ & LE & SS,PLSCD & Gr 3 alk & 6yrs & SR+HAMT & $26 / 14$ & HM & $6 / 36$ \\
\hline $4 / 56 / \mathrm{F}$ & LE & MS,PLSCD & Gr 2 alk & 9yrs & SR+HAMT & $30 / 12$ & HM & $6 / 24$ \\
\hline
\end{tabular}

M, male; F, female; Dx, diagnosis; BCVA, best corrected visual acuity; OD, right eye; OS, left eye; CED, corneal epithelial defect; SC, stromal clouding; PLI, partial limbal ischemia; TLI, total limbal ischemia; MS, mild symblepharon; SS, severe symblepharon; TLSCD; total limbal stem cell deficiency; PLSCD, partial limbal stem cell deficiency; Gr, grade (according to Roper-Hall classification); Alk, alkaline; HAMT, amniotic membrane transplantation; SR, semblepharon resection; LAT, limbal autograft transplantation; CF, counting fingers; HM, hand movements

DISCUSSION: Chemical injury of the conjunctiva and cornea is a true ocular emergency and requires immediate intervention. Chemical injuries to the eye can produce extensive damage to the ocular surface and anterior segment leading to visual impairment and disfigurement. Early recognition and treatment ensures the best possible outcome for this potentially blinding condition.

In acute burns, leukocyte infiltration and persistent inflammation prevent epithelialization, contribute to stromal melting, and may cause granuloma or scarring in the chronic stage. Chronic inflammation of the limbal stroma has been shown to be a major factors leading to stem cell deficiency in humans. (18) Conversely, despite the presence of wide ocular 
surface defects in the acute stage, some viable conjunctival and corneal stem cells are believed to remain at the basal level. (19) Therefore, when used in the early stage of chemical burns, HAMT is thought to promote healing of the ocular surface by preventing leukocyte infiltration, decreasing the duration and severity of inflammation, and protecting the epithelial progenitor cells. Through these effects, HAMT can help the healing of the ocular surface in mild to moderate (grade II or III) chemical burns in which there is only partial limbal stem cell deficiency. In severe (grade IV) burns, conversely, there is almost total limbal stem cell deficiency, deep stromal damage, and ischemia. In these cases, although HAMT may decrease stromal inflammation and vascularization, heal the conjunctival surface, and prevent symblepharon formation, it cannot prevent development of limbal stem cell deficiency. Therefore, it can be used as an adjunct to support limbal auto- or allografts where it provides an inflammation-free environment and a basal membrane on which epithelial progenital cells can survive, differentiate, and migrate. (20)

The success rate in terms of visual recovery in present study was $80 \%$ in acute burn which was similar to other studies. $(21,19)$ In severe injuries, amniotic membrane transplantation (HAMT) restores the conjunctival surface without symblepharon and reduces limbal stromal inflammation, but does better when HAMT combined with LAT as also shown in other studies. (22) Human amniotic membrane grafting (HHAMT) is a boon as acts not only as an amazing biological dressing but, also provides the basement membrane for the limbal stem cell transplantation and prevents recurrence of symblepharon in chemical injuries.

\section{REFERENCES:}

1. Van Herendael BJ, Oberti C, Brosens I. Microanatomy of the human amniotic membrane: a light microscopic, transmission and scanning microscopic study. Am J Obstet Gynecol 1978; 131:872-80

2. Kubo M, Sonoda Y, Muramasu R. Immunogenicity of human amniotic membrane in experimental xenotransplantaiton. Invest Ophthalmol Vis Sci 2001; 42: 1539-1546.

3. Ward DJ, Bennett JP. The long-term results of the use of human amnion in the treatment of leg ulcers. Br J Plastic Surg 1984;37:191-193,

4. Subrahmanyam M. Amniotic membrane as a cover for microskin grafts. Br J Plastic Surg 1995; 48:477-478.)

5. Dhall K. Amnion graft for treatment of congenital absence of the vagina. Br J Obstet Gynaecol 1984; 91:279-82.

6. Georgy MS, Aziz NL. Vaginoplasty using amnion graft: new surgical technique using the laparoscopic transillumination light. J Obstet Gynaecol 1996;16:262-264

7. Lee SH, Tseng SCG. Amniotc membrane transplantation for persistent epithelial defects with ulceration. Am J Ophthalmol 1997;123:303-312

8. Prabhasawat P, Barton K, Burkett G, Tseng SC.Comparison of conjunctival autografts, amniotic membrane grafts, and primary closure for pterygium excision. Ophthalmology 1997;104:974-985

9. Shimazaki J, Shinozaki N, Tsubota K. Transplantation of amniotic membrane and limbal autograft for patients with recurrent pterygium associated with symblepharon. $\mathrm{Br} \mathrm{J}$ Ophthalmol 1998;82:235-240

10. Tseng SCG, Prabhasawat P, Lee S-H. Amniotic membrane transplantation for conjunctival surface reconstruction. Am J Ophthalmol 1997; 124:765-774 
11. Tsai RJF, Tseng SCG. Human allograft limbal transplantation for corneal surface reconstruction. Cornea 1994; 13: 389-400.

12. Roper-Hall MJ. Thermal and chemical burns. Trans Ophthalmol Soc UK 1965;85:631640

13. Kim JC, Tseng SC. Transplantation of preserved human amniotic membrane for surface reconstruction in severely damaged rabbit corneas. Cornea 1995;14:473-484

14. Kruse FE, Joussen AM, Rohrschneider K, You L, Sinn B, Baumann J, et al . Cryopreserved human amniotic membrane for ocular surface reconstruction. Graefes Arch Clin Exp Ophthalmol 2000;238:68-75

15. Maral T, Borman H, Arslan H, Demirhan B, Akinbingol G, Haberal M. Effectiveness of human amnion preserved long-term in glycerol as a temporary biological dressing. Burns 1999;25:625-635

16. Nakamura T, Yoshitani M, Rigby H, Fullwood NJ, Ito W, Inatomi T, et al . Sterilized, freeze-dried amniotic membrane: A useful substrate for ocular surface reconstruction. Invest Ophthalmol Vis Sci 2004;45:93-99

17. Azuara-Blanco A, Pillai CT, Dua HS. Amniotic membrane transplantation for ocular surface reconstruction. Br J Ophthalmol. 1999;84:399-402

18. Puangsricharern V, Tseng SCG. Cytologic evidence of corneal diseases with limbal stem cell deficiency. Ophthalmology 1995; 102: 1476-1485

19. Meller D, Pires RT, Mack RJ, Figueiredo F, Heiligenhaus A, Park WC, Prabhasawat P, John T, McLeod SD, Steuhl KP, Tseng SC. Amniotic membrane transplantation for acute chemical and thermal burns. Ophthalmology 2000; 107: 980-989

20. Dua HS, Azuara-Blanco A. Amniotic membrane transplantation. Br J Ophthalmol 1999; 83:748-752.

21. Sridhar MS, Bansal AK, Sangwan VS, Rao GN et al. Amniotic membrane transplantation in acute chemical and thermal injury. Am J Ophthalmol. 2000; 130:134-137

22. Tseng SCG, Prabhasawat P, Barton K, Gray T, Meller D.Amniotic membrane transplantation with or without limbal allografts for corneal surface reconstruction in patients with limbal stem cell deficiency. Arch Ophthalmol. 1998; 116:431-441 


\section{BRIEF COMMUNICATION}

Case-1 in figures 1-3, Case-2 in figures 4-6

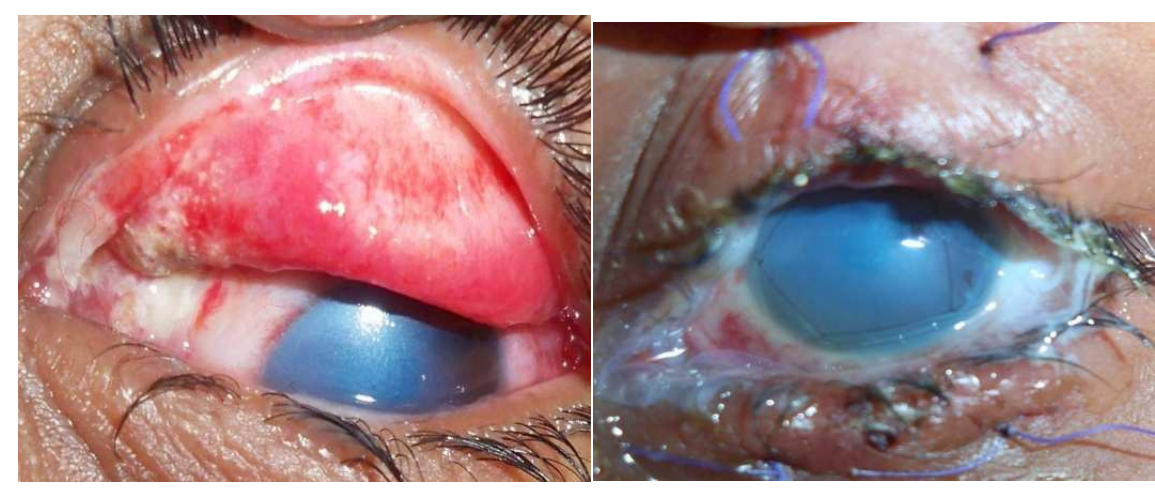

Figure-1: Pre-op (alkali burn) Figure-2: $1^{\text {st }}$ post-op day with HAMT

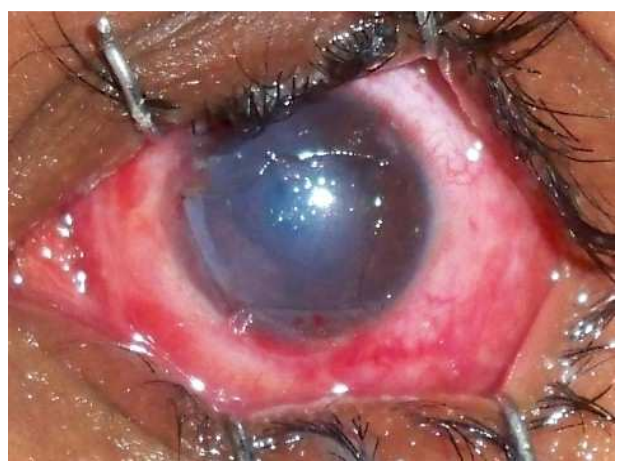

Figure-3: 3weeks post-HAMT

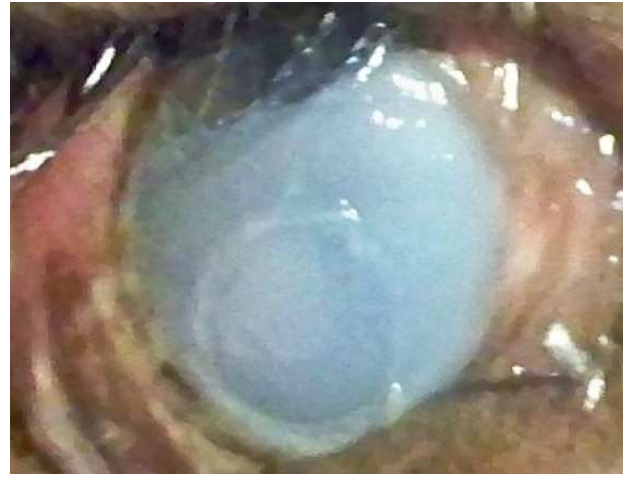

Figure-4:Pre-op (alkali burn)

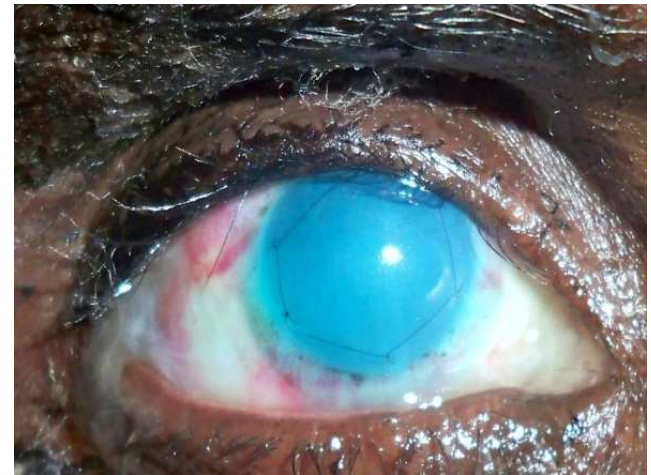

Figure-5: $1^{\text {st }}$ post-op day with HAMT

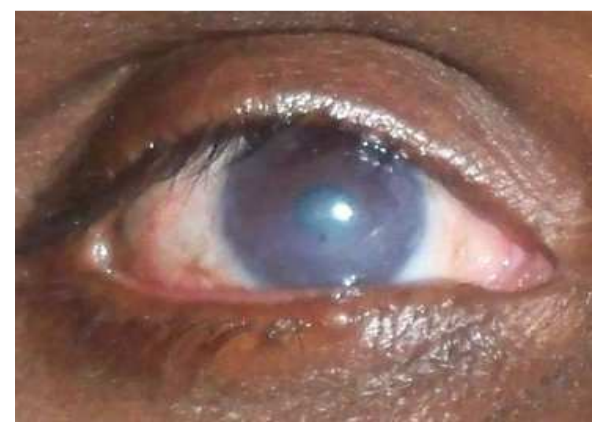

Figure-6: 3months post- HAMT 